\title{
Self Efficacy: Performance Accomplishment dan Perilaku Merokok Remaja
}

\author{
Wiwin Haryati ${ }^{1, a^{*}}$, Asnawi Abdullah ${ }^{2, b}$, Bakhtiar $^{3, c}$ \\ ${ }^{1}$ Fakultas Ilmu Keperawatan, Universitas Syiah Kuala, Banda Aceh 23111, Indonesia \\ ${ }^{2}$ Fakultas Kesehatan Masyarakat, Universitas Muhammadiyah Aceh, Banda Aceh 23245, Indonesia \\ ${ }^{3}$ Fakultas Kedokteran, Universitas Syiah Kuala, Banda Aceh 23111, Indonesia \\ a wiwinharyaty@gmail.com *; b asnawi.abdullah@gmail.com ; ${ }^{\mathrm{c}}$ bakhtiar@ unsyiah.ac.id \\ * corresponding author
}

ARTICLE INFO

Keywords

Performance accomplishment

Smoking Behavior

Teenagers

Self Efficacy

\begin{abstract}
Smoking behavior among teenagers has been increasing worldwide, triggering youth morbidity and mortality rates associated with smoking illnesses. Performance accomplishment, source of self-efficacy, has a significant influence on the high proportion of teenage smoking behavior. The purpose of this study was to assess the relationship between performance accomplishment and teenage smoking behaviors. The study was conducted on April 16 - 23, 2015 in Aceh Province, Indonesia. Data were collected by disseminating a Likert scale questionnaire, consisting of general perceived self-efficacy, including performance accomplishment. The population of this study were 4,856 students, with a total sample of 368 students from 13 senior high schools. The study employed an analytic observational research design with the stratified proportional random sampling technique. Bivariate analysis by Chi-square test was applied to examine the data, processed by using SPSS version 20.0. The results indicated that there were significant relationships between self-efficacy and teenage smoking behavior $(\mathrm{p}=0.0001)$ and between performance accomplishment and teenage smoking behavior $(\mathrm{p}=0.0001)$. This study concluded that performance accomplishment has been strongly associated with the smoking behavior among young adults.
\end{abstract}

\section{Pendahuluan}

Remaja merupakan generasi penerus bangsa ini, generasi yang diharapkan akan produktif dan menghasilkan suatu yang positif. Remaja diharapkan dapat membawamanfaat yang besar pada negara ini. Remaja dikarakteristikan dengan rasa ingin tahu yang tinggi (high curiosity), ingin berpetualang, menjelajahi segala sesuatu, dan mencoba segala sesuatu yang belum pernah dialaminya termasuk keingintahuan tentang rokok [1].

Merokok pada remaja diakibatkan karena pencarian identitas diri seorang remaja akibat adanya perubahan drastis perkembangan pesat remaja baik fisik maupun psikis. Memasuki remaja diibaratkan memasuki masa badai dan stress dalam perkembangan jiwa seseorang [2].

Data menurut WHO menunjukkan bahwa negara Indonesia merupakan negara dengan jumlah perokok ketiga terbesar di dunia setelah Cina dan India. DImana jumlah perokok 30\% adalah usia remaja [3]. Data Kementrian Kesehatan melalui Riset Kesehatan Dasar (Rikesdas) tahun 2010 diperoleh bahwa jumlah perokok di Indonesia mencapai 34,7 persen. Perokok yang paling banyak terdapat di Kalimantan Tengah, sementara konsumsi batang rokok perhari paling banyak di Provinsi Bangka Belitung. Kategori jumlah perokok berat yang menghabiskan lebih dari 
31 batang/hari, Provinsi Bangka Belitung tertinggi 16,2 persen kemudian Provinsi Aceh sebanyak 9,9 persen (Rikesdas, 2010) [4]. Remaja merokok didasari berbagai alasan. Salah satunya menurut Bandura (1995), bahwa perilaku merokok dipengaruhi oleh selfefficacy (keyakinan diri) seseorang. Selfefficacy adalah penilaian seseorang akan kemampuannya atau menampilkan kompetensi, meraih tujuan, atau mengatasi suatu hambatan [5]. Bradley \& Corwyn (2001) mengatakan bahwa self efficacy dapat menurunkan perilaku merokok pada remaja, yaitu dengan cara penguatan self efficacy pada diri remaja [6].

Seseorang yang memiliki performance accomplishment (pengalaman yang pernah dicapai oleh individu) yang tinggi, biasanya menghadapi tantangan baru dengan optimis, dan mereka menetapkan tujuan yang tinggi bagi diri mereka sendiri. Selain itu self efficacy juga mempengaruhi bagaimana seseorang mengatasi kekecewaan dan stress dalam mengejar hidup [7].

Performance accomplishmentadalah prestasi yang pernah dicapai pada masa yang telah lalu. Sebagai sumber, performansi masa lalu menjadi pengubah self efficacy yang paling kuat pengaruhnya. Prestasi (masa lalu) yang bagus meningkatkan efficacy expectation, sedang kegagalan akan menurunkan selfefficacy [7].

Menurut Gwaltney et.al (2009) menyatakan bahwa self efficacy merupakan tolak ukur perilaku seseorang. Bila dikaitkan dengan perilaku merokok remaja self efficacy yang tinggi akan menjadi peredam keinginan untuk mencoba merokok atau berhenti merokok. Sebaliknya self efficacy seseorang rendah/lemah membuat seseorang terjerumus untuk mengkonsumsi rokok bahkan obat-obat terlarang walaupun seseorang tahu bahwa merokok merusak kesehatannya.

\section{Metode}

Penelitian ini telah dilakukan pada tanggal 16 April sampai dengan 23 April 2015. Penelitian ini termasuk jenis penelitian analaitik observasional dengan desain penelitian cross sectional study. Dalam penelitian ini yang dinilai adalah hubungan self efficacy dengan perilaku merokok remaja khususnya pada performance accomplishment.

Populasi adalah keseluruhan objek yang diteliti sedangkan sampel adalah sebagian yang diambil dari keseluruhan objek yang diteliti dan dianggap mewakili seluruh populasi dengan menggunakan cara/teknik sehingga sampel ini sedapat mungkin dapat mewakili keseluruhan populasi. Yang menjadi populasi dalam penelitian ini adalah seluruh remaja di Sekolah Menengah Atas, dengan dasar pemilihan sampel dengan tehnik stratified proportional random sampling. Populasi dalam penelitian ini berjumlah 4856 siswa/i dari tiga belas Sekolah Menengah Atas di Banda Aceh. Sampel yang diikutsertakan dalam penelitian ini berjumlah 368 remaja dari 13 sekolah yang dipilih secara acak. Data di analisis dengan menggunakan SPSS versi 20.00. Analisa data univariat dilakukan pada tiap-tiap variabel dan disajikan dalam bentuk frekuensi dan persentase. Analisa univariat bertujuan untuk mendapatkan gambaran deskriptif dari setiap variabel.Analisis uji bivariate yang digunakan adalah uji chi-square karena data bersifat kategorik, untuk melihat hubungan self efficacy dan performance accomplishment dengan perilaku merokok remaja.

\section{Hasil dan Diskusi}

\section{Hubungan Health Belief dengan Kepatuhan Pasien Hemodialisis Dalam} Pembatasan Cairan Gambaran Karakteristik Remaja

Tabel 1. Distribusi Frekuensi Karakteristik Remaja (n=368)

\begin{tabular}{llccc}
\hline No. & Variabel & Kategori & F & \% \\
\hline 1. & Umur & $10-13$ tahun & 0 & 0 \\
& & $14-15$ tahun & 94 & 25,5 \\
& & $16-19$ tahun & 274 & 74,5 \\
\hline 2. & Kelas & Kelas 1 & 122 & 33,2 \\
& & Kelas 2 & 69 & 18,8 \\
& & Kelas 3 & 177 & 48,1
\end{tabular}




\begin{tabular}{|c|c|c|c|}
\hline 3. Jenis Kelamin & $\begin{array}{c}\text { Laki-laki } \\
\text { Perempuan }\end{array}$ & $\begin{array}{l}195 \\
173\end{array}$ & $\begin{array}{l}53 \\
47\end{array}$ \\
\hline & & 368 & 100 \\
\hline
\end{tabular}

Berdasarkan tabel 1 di atas diketahui bahwa variabel umur didominasi pada umur 16-19 tahun sebanyak 274 orang $(74,5 \%)$. Untuk variabel kelas didominasi kelas 3 sebanyak 177 orang $(48,1 \%)$, untuk variabel asal sekolah didominasi oleh SMA 3 sebanyak 65 orang $(17,7 \%)$, untuk variabel jenis kelamin didominasi oleh jenis kelamin laki-laki sebanyak 195 orang (53\%).

\section{Perilaku Merokok}

Tabel 2. Distribusi Frekuensi Perilaku Merokok Remaja

\begin{tabular}{|c|c|c|c|}
\hline No. & Kriteria & Frekuensi & Persentase \\
\hline 1. & Merokok & 47 & 12,8 \\
\hline 2. & Tidak Merokok & 321 & 87,2 \\
\hline & Jumlah & 368 & 100 \\
\hline
\end{tabular}

Berdasarkan tabel 2 di atas diketahui bahwa distribusi frekuensi perilaku merokok remaja terbesar dengan kategori merokok sebanyak 47 orang $(12,8 \%)$.

\section{Gambaran Performance Accomplishment (Kemampuan diri sendiri) Remaja}

Distribusi frekuensi performance accomplishment responden dapat dilihat pada tabel 3 sebagai berikut:

Tabel 3. Distribusi Frekuensi Performance Accomplishment Remaja

\begin{tabular}{llccc}
\hline No. & & Kriteria & Frekuensi & Persentase \\
\hline 1. & Tinggi & & 239 & 64,9 \\
2. & Rendah & 129 & 35,1 \\
\hline & Jumlah & 368 & 100 \\
\hline
\end{tabular}

Berdasarkan tabel 3 di atas diketahui bahwa distribusi frekuensi terbesar performance accomplishment responden berada pada kategori tinggi sebanyak 239 orang $(64,9 \%)$.

\section{Analisa Hubungan Performance Accomplishment dengan Perilaku Merokok Remaja}

Tabel 4. Hubungan performance accomplishment terhadap perilaku merokok remaja

\begin{tabular}{|c|c|c|c|c|c|c|c|c|c|}
\hline \multirow{3}{*}{$\begin{array}{c}\text { Performance } \\
\text { accomplishment }\end{array}$} & \multicolumn{4}{|c|}{ Perilaku Merokok } & \multirow{2}{*}{\multicolumn{2}{|c|}{ Total }} & \multirow{3}{*}{$\begin{array}{l}\text { Nilai } \\
\alpha\end{array}$} & \multirow{3}{*}{$\begin{array}{c}\mathrm{P} \\
\text { Value }\end{array}$} & \multirow[t]{3}{*}{ OR $(95 \% \mathrm{CI})$} \\
\hline & \multicolumn{2}{|c|}{ Merokok } & \multicolumn{2}{|c|}{$\begin{array}{c}\text { Tidak } \\
\text { Merokok }\end{array}$} & & & & & \\
\hline & $\mathrm{N}$ & $\%$ & $\mathrm{n}$ & $\%$ & $\mathrm{n}$ & $\%$ & & & \\
\hline Tinggi & 7 & 2,9 & 232 & 97,1 & 239 & 100 & 0,05 & 0.000 & $14,896(6,435-$ \\
\hline Rendah & 40 & 31,0 & 89 & 69,0 & 129 & 100 & & & $34,482)$ \\
\hline Jumlah & 47 & 12,8 & 321 & 87,2 & 368 & 100 & & & \\
\hline
\end{tabular}

Berdasarkan tabel 4 diketahui bahwa hubungan performance accomplishment dengan perilaku merokok remaja dengan kategori performance accomplishment rendah sebanyak 35,0\% sedangkan yang performance accomplishment tinggi sebanyak 2,9\%. Hasil uji Chi Square di 
peroleh $\mathrm{P}$ value $=0,000$ artinya $\mathrm{p}$ value $<$ nilai alfa $(0,05)$, sehingga disimpulkan ada hubungan antara performance accomplishment dengan perilaku merokok remaja. Tabel 3 juga menunjukkan bahwa Confidence Interval (CI) 95\% diperoleh odds - ratio (OR) 14,896 (6,435-34,482), artinya Performance accomplishment yang rendah 14,896 kali mempunyai hubungan dengan perilaku merokok remaja dibandingkan dengan performance accomplishment yang tinggi.

\section{Pembahasan}

Ada hubungan yang significant antara performance accomplishment dengan perilaku merokok remaja. Hal ini sejalan dengan penelitian Veselka, Geckova, Reijneveld dan Dijk (2010) yang menyatakan bahwa ada hubungan yang significant antara performance accomplishment, sosial dan status emosional remaja dengan kejadian perilaku merokok remaja.

Hal ini sesuai dengan pendapat Bandura (2001) yang menyatakan bahwa individu mendapatkan self efficacy nya berdasarkan empat sumber sebagai berikut: 1) performance accomplishment (pengalaman keberhasilan diri sendiri di masa lalu);2) vicarious experience (pengalaman orang lain); 3) social persuation (pengaruh sosial/lingkungan); dan 4) emotional arousal (keadaan emosi seseorang) [7].

Seseorang yang memiliki performance accomplishment (pengalaman yang pernah dicapai oleh individu) yang tinggi, biasanya menghadapi tantangan baru dengan optimis, dan mereka menetapkan tujuan yang tinggi bagi diri mereka sendiri. Selain itu self efficacy juga memengaruhi bagaimana seseorang mengatasi kekecewaan dan stress dalam mengejar hidup [7]. Performance accomplishmentadalah prestasi yang pernah dicapai pada masa yang telah lalu. Sebagai sumber, performansi masa lalu menjadi pengubah self efficacy yang paling kuat pengaruhnya. Prestasi (masa lalu) yang bagus meningkatkan efficacy expectation, sedang kegagalan akan menurunkan selfefficacy [7].

Performance accomplishment adalah prestasi yang pernah dicapai pada masa yang telah lalu. Performance masa lalu menjadi pengubah pengubah self efficacy yang paling kuat pengaruh nya. Prestasi di masa lalu yang bagus meningkatkan self efficacy, sedangkan kegagalan akan menurunkan self efficacy. Peneliti berasumsi bahwa ada hubungan yang significant antara performance accomplishment dengan perilaku merokok remaja. Makin tinggi performance seseorang khususnya remaja makin tinggi self efficacy seseorang. Makin tinggi performance accomplishment seseorang maka perilaku merokok remaja makin rendah.

Dari hasil penelitian ini menunjukkan bahwa:

1. Health belief pasien hemodialsisis di RS Murni Teguh Medan tahun 2019 rata-rata health belief tinggi adalah 112 (74,7\%) sedangkan health belief rendah adalah 38 (25,3\%).

2. Kepatuhan pasien hemodialsis dalam pembatasan cairan dan garam di RS Murni Teguh Medan tahun 2019 rata-rata Patuh adalah 106 (70,7\%) sedangkan tidak patuh sebanyak 44 (29,3\%).

3. Terdapat hubungan yang positif health belief dan kepatuhan pasien bersifat positif.

\section{Kesimpulan}

Hasil penelitian diperoleh bahwa ada hubungan yang significant antara self efficacy dengan kejadian perilaku merokok remaja dan ada hubungan yang significant juga antara performance accomplishment dengan kejadian perilaku merokok remaja. Perilaku merokok remaja disebabkan karena self efficacy dan performance accomplishment yang rendah. Karenanya perlu ditingkatkan lagi self efficacy remaja dengan cara meningkatkan performance accomplishment remaja. Performance accomplishment dapat ditingkatkan melalui kegiatan ekstrakurikuler di sekolah meliputi kegiatan olahraga dan seni, maupun dalam bidang prestasi akademik di kelas.

\section{Referensi}

[1] Santrock (2002). Perkembangan anak. Edisi 11. Jilid 1. Penerbit buku Erlangga: Jakarta.

[2] Lestari \& Purwandari (2012). Perilaku merokok pada remaja SMA/SMK di Kota dan Luar

[3] WHO (2011). Indikator perbaikan kesehatan lingkungan anak. Jakarta: EGC.

[4] Riset Kesehatan Dasar (2010). Peringkat konsumsi rokok di indonesia: Jakarta. 
[5] Bandura, A (1995). Self efficacy in changing societies. New York: Cambridge University Press.

[6] Bradley, R.H, \& Corwyn, R.F, (2001). Home environment and behavioral development during early adolescence: The mediating and moderating role ofself efficacy beliefs.

[7] Bandura, A (2001). Self efficacy and health. In N.J. Smelser \& P.B. Baltes (Eds). International encyclopedia of the social and behavioral sciences, Vol. 20.

[8] Leganger, Kraft and Roysane (2002). Relationship between performance toward accomplishment and self afficacy.

[9] Schuck, Otten, Kleinjan, Bricker \& Engels (2014). Self efficacy and acceptance of cravings to smoke underlie the effectiveness of quitline counseling for smoking cessation. http://www. ncbi.nlm.nih.gov/pibmed/25042212. Diakses tanggal 12 Nopember 2014.

[10] Tahlil T, Woodman RJ, Coveney J, Ward PR. (2015). Six-months follow-up of a clusterrandomized trial of school-based smoking prevention education programs in Aceh,Indonesia. BMC Public Health. 15:1088. doi:10.1186/s12889-015-2428-4. 